18世紀後半から19世紀初頭エジプトにおける ハルワティーヤ教団組織再考

—ーアフマド・アッサーウィー（1761-1825）の伝記の分析から-

Reconsideration on the Organization of al-Khalwatiyya in Egypt from the Latter Half of 18th Century to the Beginning of 19th Century:

An Analysis of the Biography of Aḥmad al-Ṣāwī (1761-1825)

高 橋
TAKAHASI Kei

ABSTRACT The present article intends to reconsider the reflections made regarding the illustrations of Sufi orders in Ottoman Egypt, through examination of the organization of al-Khalwatiyya.

Studies on the organization of Sufi orders in Ottoman Egypt face two major drawbacks. First, their approaches are based on the modern concept of "institution," neglecting the members' perceptions of the orders they adhere to. Second, the studies describe the conditions of the Sufi orders exclusively within the context of popular culture, ignoring approaching such a phenomenon as the product of high culture.

Given that al-Khalwatiyya was wide-spread among the 'Ulamā' of Azhar, the present study scrutinizes the conditions of a given Sufi order in a society of learned. By making use of hagiographical texts (manāqib) written by members of al-Khalwatiyya, and also, the chronicles of al-Jabartī, a member of the order in question, as main referential sources, the scrutiny would be rather draw on the perceptions of the members of the order.

The organization of al-Khawatiyya, as illustrated in the sources cited above, is as follows. While, past studies described it as being divided into several sub-orders, the members of the order never viewed themselves as

* 上智大学大学院博士課程

Ph. D. Student, Sophia University 
such. They rather perceived that they belonged to a țarīqa, in this case, alKhalwatiyya. Such does not deny that their activities were not confined to small groups. So al-Khalwatiyya's orginzation could be perceived as bidimensional: a tarīqa, to be viewed as a mode of devotion rather than as a social group, and, and master-centered groups, where actual religious activities took place.

Also, one should not consider the group's organization as rigid, for it consisted of the direct bond linking the master to his pupils, while and interfollowers ties were quite weak, leading to its disintegration once the master passed away.

In conclusion, these perceptions of al-Khalwatiyya as reflected in the selected sources indicate that the organization of Sufi orders was totally different from that of modern "institution."

\section{I. 問題の所在}

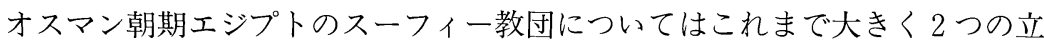
場からの研究がなされてきたと言えるだろう。一つは夕リ一力研究とでも呼べ る立場であり，それは特定の教団の教義・儀礼・系譜を対象とする思想的ある いは通時的な研究である。もう一方は社会史的立場であり，そこでは教団はギ ルドや街区と並ぶ社会集団の一つとしてその組織や役割が明らかにされてき た。しかしいずれの立場の研究もまず量的に不十分であり，またそこで踏襲さ れてきた姿勢にはいくつかの問題点が見出される。まず前者の立場においては 教義を支える思想や学識高いスーフィーたちの活動や系譜を見ることができる が，一方で教団の社会的様相には関心が向けられなかった。後者の立場におい ては本来階層的・文化的越境性を持っているスーフィズムが専ら民衆文化の枠 の中でしか語られず，タリ一カ研究で扱うような思想的側面や歴史性との関連 付けが不十分だった。

またもう一つの問題点としては, 教団を扱う前提の認識において E.W.レイン のようにそれを特定の職業や階層と結びついた固定的な集団として捉える視 (3)

点が無批判に踏襲されていたり，あるいは現代のような教団組織の存在が想定 されるなど, 総じてこの時期の教団があまりにも近代的な「組織」として捉え られていることである。そしてこのような見方が踏襲されてきた原因の一つは， 
同時代の教団のメンバー自身による教団に対する認識に全く注意が払われてこ なかったことがあるだろう。

M.ウィンターはこうしたタリーカ研究と社会史的研究の両方の立場をまと めた優れた概説を書いているが，そこでも上記の問題点はそのまま踏襲されて いる。まず彼は少なくとも「18世紀までにスーフィー教団が結晶化し組織とし てより厳密になった」と述べているが，教団組織の実態の解明が進んでいない 現状においてはその主張をそのまま受け入れることはできないだろう。

また，個別の教団の説明において彼は教団を「民衆的教団」と「エリート的

教団」とに分類しているが，そこでは民衆的教団に関してはその社会的役割な どが論じられる一方で，エリート的教団については実質上その担い手の系譜や 教団の性格の説明に終始しており，両者の扱い方には質的な相違が見られる。

上記のウィンターの概説に如実に現れている，これまでの研究の認識上の問 題点をまとめれば次の 2 つになるだろう。まず教団の組織の実態が明らかに なっていないにも関わらず，その組織の厳密性が無批判に信じられている。ま た「民衆的教団」と「エリート的教団」という分類がなされているが，結局の ところそれはこれまでのタリーカ研究と社会史的研究の分裂を踏襲しており， 特にエリートの社会の中での教団のあり方についての検討がなされてこなかっ た。

本稿は，個別の教団の組織の実態の解明を通じて，このような認識のもとに 論じられてきた従来の一般的なスーフィー教団像を見直し，新たな認識の枠組 みを構築するための道を示すことを目的とする。具体的には，18世紀の半ばに エジプトにもたらされて広まったハルワティーヤ教団 al-Khalwatiyya を考察 の対象とする。この教団はアズハルのウラマーの間に普及したことからエリー 卜的教団の代表的なものと考えられ，これまでの研究は専らその教義や系譜の 説明に終始してきた。これに対して本稿では学識者の社会の中でのこの教団の あり方の解明を試みる。

主要史料としては同時代（18世紀末から19世紀初頭）のハルワティーヤのメ ンバーたちによって書かれた聖者伝 (manāqib) を使用する。この聖者伝『聖者 の長の美徳と奇蹟における光と輝き』は，ハルワティーヤの著名なシャイフで マーリク派の法学者でもあったアフマド・アッサーウィーAhmad al-Ṣāwī （1761-1825）(以後サーウィーと記）の生涯を，その弟子でやはりアズハルの教 
師であったカースィム・アッシシュティーQāsim al-Shishtīi, アフマド・アッシ シュティー Ahmad al-Shishtī (d. 1820), ムハンマド・アルクトゥビー Muhmmad al-Kutubī らが記述した伝記である。この伝記はハルワティーヤ教 団の客観的な説明を意図したものではなく，またその著者たちもアズハルの学 識者という点で史料としての限界があるが，そこからは同時代の教団のメン バー自身の教団に対する認識を明らかにすることができるだろう。そしてこれ は上述のようにこれまでの研究では顧みられていなかった視点である。

またこの時期の基本史料であるジャバルティー 'Abd al-Rahmān al-Jabartī (1753-1825/26) の年代記も主要史料として使用する。ジャバルティー自身も八 ルワティーヤのメンバーであり, 従ってこの年代記は単なる情報源としてだけ ではなく，伝記と同じくメンバー自身の教団に対する認識を探る史料としても 価値があるものである。

本稿の構成としては，この伝記の対象人物であるアフマド・アッサーウィー の教団における活動について述へ，その上でそこから読み取れるハルワティー ヤ教団の組織についての考察を行うが，まず始めにエジプトにおけるハルワ ティーヤ教団の歴史を概観し，18世紀に活動した主なメンバーを紹介する。

\section{II. オスマン朝期エジプトにおけるハルワティーヤ教団の系譜}

ハルワティーヤは15世紀頃にコーカサスで誕生し，アナトリアに広まった教 団である。オスマン朝の庇護の下で正統的・スンナ派擁護の教団として確立し， 16世紀以降多くの支教団が成立した。エジプトにはそのうちの一つカラバシー ヤ教団 al-Qarabashiyya の流れが，エルサレム出身のムスタファ・アルバク リーMuștafā Kamāl al-Dīn al-Bakrī (1688-1749) によってもたらされた。 の際に彼はアズハルのアーリムで後にシャイフ・アルアズハルとなる（位17571767）ムハンマド・アルヒフニー Muhammad Sālim al-Ḥifnī (1688-1767) に タリーカを伝え，このヒフニーを起点としてアズハルのウラマーたちにハルワ ティーヤは広まっていった。

ヒフニーの弟子たちの中で特に重要と考えられるのはマフムード・アルクル ディーMahmūd al-Kurdī (1715-1781) とアフマド・アッダルディール Ahmad al-Dardir (1715-1789) の 2 人である。

マフムード・アルクルディーはハルワティーヤにおけるジャバルティーの師 
でもあり，年代記の中ではヒフニーの一番弟子のように描かれている。またク ルディーの弟子にはやはりシャイフ・アルアズハルとなる（位1793-1812）アブ ドゥッラー・アルシャルカーウィー 'Abdullāh al-Sharqawī (1737-1812) がい (13) る。

アフマド・アッダルディールははむしろアーリムとして有名であり，アズハル においてはマーリク派のシャイフ (shaykh al-Mālikiyya), 上エジプトの人々 のワクフの管理人 (nāẓir 'alā waqf al-Sa‘āida), 上エジプトの学生のリワーク (shaykh 'alā țā'ifat al-riwāq) といった地位にあった。年代記においてはハル ワティーヤのスーフィーというよりはむしろそうしたアーリムとしての側面が 専ら語られている。しかし彼は，本稿で扱うサーウィ一をはじめとして，19世 紀以降のハルワティーヤの拡大に貢献したスーフィーたちー例えばサーリフ・ アッスイバーイー Șālih al-Sibā‘ī (1741/42-1806/07)やアブドゥルアリーム・ アッサンフーリー ‘Abd al-'Alīm al-Sanhūrī (d. 1799/1800)の師として重視す ベき存在である。

19世紀以降こうしたメンバーを起点としてハルワティーヤはエジプト全土や アフリカへと広がってゆくことになるが，この点に関しては稿を改めて論じる つもりである。

\section{III. アフマド・アッサーウィーの教団における活動}

サーウィーの伝記はその内容から大きく 2 つの部分に分けることができる。 その出生から師ダルディールの死を経てスーフィー・シャイフとなるまでの前 半部分では，彼がハルワティーヤ教団の一人のムリードとして実践した様々な 倫理（akhlāq）が列挙されている。一方後半部分では聖者（walī）として彼の 奇蹟 (karāmāt) や美徳 (manāqib) が列挙されている。つまりこの後半部分で は彼はハルワティーヤ教団のスーフィーという枠では扱われず，より普遍的な 聖者として語られている。ただし本稿の目的は聖者としてのアフマド・ アッサーウィーの姿を示すことではなく，あくまでも彼を通して現れるハルワ ティーヤ教団の姿を捉えることにある。従って本稿においては伝記における前 半部分, すなわちサーウィーが夕リーカの修行を終えてシャイフとなるまでの 時期を専ら扱う。

アフマド・アッサーウィー Ahmad al-Ṣāwī al-Mālikī al-Khalwatī は1761年 
表：ハルワティーヤ主要メンバー一覧

\begin{tabular}{|c|c|c|}
\hline 名 前 - 生 没 年 & 法 & 出身 地 \\
\hline Mușțafā Kamāl al-Dīn al-Bakrī(1688-1749) & $\mathrm{H}$ & Quds \\
\hline -Abd al-Karīm al-Sammān(1718-1775) & $?$ & Madīna (Ḥijāz) \\
\hline LMuhammad Sālim al-Hifnīî̀(1688-1767) & $\mathrm{S}$ & Ḥifna Bi’l-Qașr(Bilbays) \\
\hline -Abd al-Karìm al-Zayyāt(d. 1767) & $\mathrm{S}$ & $?$ \\
\hline -Muhammad al-Samannūdī al-Munīr (1687/88-1784/85) & $\mathrm{S}$ & Samannūd \\
\hline -'Alī al-Qināwī (d. 1784) & $?$ & Qinā \\
\hline -Hẹan 'Alī al-Makkī (1729/30-1763) & $?$ & Makka (Hijāz) \\
\hline -Sulaymān al-'Ujaylī al-Jamāl(d. 1790) & $\mathrm{S}$ & Minyatal-'Ujayl (Gharbiyya) \\
\hline -Hasan al-Shībīn al-Fuwwī (d. 1769/70) & $\mathrm{S}$ & Fuwwa \\
\hline L'Alī al-Rashīdī & $?$ & Rashīd \\
\hline -Maḥmūd al-Kurdì (1715-1781) & $\mathrm{S}$ & $?$ \\
\hline -'Abdullāh al-Sharqāwī (1737/38-1812) & $\mathrm{S}$ & Tawila (Bilbays) \\
\hline -Muhammad al-Saqqāṭ(d. 1794) & $?$ & (Maghrib) \\
\hline LMuhammad Sīrīn al-Maqdisī (1747-1805) & $\mathrm{S}$ & $?$ \\
\hline LAhmad al-Dardir (1715-1786) & M & Banì 'Adi (Minyā) \\
\hline -Șālih al-Sibā'î̀ (1741/42-1806/07) & M & Banī 'Adi (Minyā) \\
\hline -'Abd al-'Alīm al-Sanhūrī (d. 1799/1800) & $\mathrm{M}$ & Sanhūr (Fayyūm) \\
\hline -Aḥmad al-Ṣāwī (1761-1825) & M & Sạ̄'l-Hajar (Gharbiyya) \\
\hline LIbrāhīm al-Shulqāmī (d. 1818) & $?$ & Shulqām(Minyā) \\
\hline L'Abd al-Lațif al-Qāyātī (1765-1842) & $\mathrm{S}$ & Qāyāt(Minyā) \\
\hline
\end{tabular}

・本表には, 伝記や年代記に見出されるハルワティーヤのメンバーのうち, ハルワティーヤのスー フィーとしての活動をおこなっていたことが確認された人物のみを記載。

・人名, 生没年, 法学派, 出身地の順に記載。

・法学派の略記は以下のとおりである。 $\mathrm{S} ：$ シャーフィイー派 $\mathrm{M}$ ：マーリク派 $\mathrm{H}$ ：ハナフィー 派

ガルビーヤのナイル岸にあるサール・ハジャル Șā'l-Hajar という町に生まれ た。父親はアーリムであり，金持ちで，信心深かった。一方母親はブハイラの アラブ遊牧民の娘であり，シャリーファであった。彼は 2 歳半の時からコーラ ンの暗誦を始め，幼くしてコーランの暗誦を終えた。そして1772-73年およそ12 歳でカイロに上りアズハルで学ぶ学生となった。

アズハルでは数多くの教師に学んだ。伝記においては主な教師として 7 人の 名前が挙がっているが，そのうち 5 人がマーリク派の教師である。その中でも 彼が特に強く結びついたのはアフマド・アッダルディールとやはりマーリク派 のムハンマド・アルアミール Muhammad al-Amīr (1742-1817)であった。そし てサーウィーはアズハルに来て 6 ケ月後にダルディールの導きでハルワティー 
ヤに入信しだ。サーウィーは専らマーリク派の教師とつながりを持ち，そうし た教師によって同時にタリ一カにも入信したが，このように法学派（それ以外 では地縁やエスニシティ）によって特定の教師と結びつき，その後その教師に よってタリーカに入信するというのも，この時期のアズハルの学生のあり方と して一般的なことである。

彼が夕リーカに入ってまず教えられたのはズィクルとウィルドの方法であっ たと思われる。ダルディールの書いた教団規約にはかなり詳細にその手順など が記載されている。ただしこれらの指導の対象は専門のスーフィーたちに限ら れていたわけではないよjである。一般の人（'āmma）にそれが教えられるこ ともあったじ，また夕リーカに入信しないでズィクルだけを学ぶ学生やウラ マーもいた。

本格的な修行を行うメンバーは7つの階梯を上ってゆき，全ての階梯を上り きった人物は弟子を取ってタリーカを指導することを許可するイジャーザ (“ijāza) を与えられる。この階梯の上昇は師が弟子の様子を見て決定するのだ が，そこでは弟子の行為や言葉の状態，そして夢などに現れる啓示が重要な要 素となった。

全体としての活動は定期的におこなわれるマジュリスが中心となる。通常は 毎週金曜日の集団礼洋の後にそれぞれの教団のザーウィヤや廟などで開催され た。ダルディールは自らのザーウィヤを持っており, 恐らくはそこでマジュリ スが開かれたものと思われる。マジュリスの構造は師と弟子との一対一の関係 が基本となっていた。タリ一カの活動においては自分の師に絶対的な忠誠を尽 くすことが要求されるので, 同じハルワティーヤのシャイフであっても, 他の 師のマジュリスに参加して学ぶことは好まれていなかったようである。例えば ある時マフムード・アルクルディーの下でズィクルの会が催されることになり， ダルディールとその弟子たちもそれに招かれた。多くの弟子たちが喜び勇んで クルディーの下に向かおうとするのに対して, サーウィーだけは師への忠誠心 から，師に諭されるまで黙して動かなかった。

サーウィーはダルディールのマジュリスにおいてタリーカの修行に熱心に取 り組み，伝記によれば弟子たちの中で誰よりも早くイジャーザを与えられたと

うう。しし彼はなぜかすぐに弟子をとることはせず，他の教団に入信してそ こでもイジャーザを得ている。彼の入信した教団とそのシャイフは以下のとお 
クである。

まず彼はアブドゥルラフマーン・アルガライニー Abd al-Rahmān alGharaynī によってシャージリーヤ教団 al-Shādhiliyya のイジャーザを与えら れた。ガライニーもやはりアズハルのアーリムであった。またアーラビー・ア ルバイルーティー A'rabī al-Bayrūtī という人物によってカーディリーヤ教団 al-Qādiriyya のイジャーザを与えられている。この人物については詳細は不明 である。また当時ダムルダーシーヤ教団の長であったムハンマド・アルダムル ダーシー Muhammad al-Damurdāshī (d.1780)によってそのイジャーザを与 えられている。そして最後にダルディールと同様にサーウィーとの結びつきが 強かった師ムハンマド・アルアミールによって全てのタリーカ（jāmi‘ țuruq alșuffiyya) のイジャーザを与えられたという。これがどのようなイジャーザなの かは不明である。ムハンマド・アルアミール自身は伝記においてはアイダルー ス教団 al-Aydarūs に，年代記においてはシャージリーヤ教団に入信していた と述べられている。

その間に彼の同胞たち（具体的にはサーリフ・アッスィバーイーとアブドゥ ルアリーム・アルサンフーリー）もイジャーザを得，間もなくダルディールの 下を離れて自らがシャイフとなるマジュリスを開くようになる。1786年にダル ディールが死亡すると，サーウィーは教団における活動の場を失う。するとす でに独立していた同胞たちが彼に自らのマジュリスに加わるように促した。伝 記には次のように記されている。

教師ダルディールが (神の下に) 運ばれた時, 活動的で完全で成功したアー リムであり，啓蒙的な諸講義と無比の証明を行う者であったシャイフ・ア ブドゥルアリーム・アルファイユーミーと, 聖者でありスーフィーであり 信心梁い禁欲家のシャイフ・サーリフ・アッスィバーイーーこの 2 人に神 が満足しますように一が夕リーカへの入信に従事していた。2 人はそれぞ れ我が教師（サーウィ一）に彼らのマジュリス（majlisi-hi）すなわち彼ら が長 (kabīr) である（マジュリス）への出席を求めた。しかし我が教師は 嘆きと無関心の衣を着て彼ら（の申し出）を断った。

最終的にサーウィーが独自のマジュリスを開いて活動を開始するのは4つの 夢によって聖者たちの許可が下りたことがきっかけになる。これらの夢では, ムハンマドをはじめとする預言者たちやアフマド・バダウィーのような聖者た 
ち, さらにはサーウィーの師であるダルディールは勿論のこと，シャージリー ヤにおける師ガライニーなども現れて彼にマジュリスを開く許可を与えてい (39)

る。

\section{IV． ハルワティーヤ教団組織の実態}

ここで今一度スーフィー教団の一般的な定義を確認し, その上でハルワ ティーヤ教団の構造についての考察に入ろう。

史料に現れる țarīqa という用語は通常「スーフィー教団 (Sufi order)」と訳 される。本稿でもこれまで史料において țarīqa という言葉で表現されるものを あえて慣行に従って「教団」と呼んできた。他方概説などでスーフィー教団の 組織が説明される際, それは通常 1 人のスーフィー・シャイフによって率いら れるヒエラルキー的な構造を持った社会集団として認識される。弟子たち（ム リード）がその 1 人のシャイフに対して「死体洗浄人の前の死体のごとく」従 う義務を負っているということも良く知られている。

このような認識をハルワティーヤ教団にあてはめると, それが 1 つの「教団」 としては捉えられないことがすぐに明らかになる。冒頭のハルワティーヤ教団 の説明で述べたように，そこにはシャイフと呼ばれるような人物が無数に存在 する。サーウィーはそうしたシャイフの一人ダルディールを師として修行を 行ったが，例えば少なくともその当時力イロにはそれ以上に有名なシャイフと してマフムード・アルクルディーがおり, 彼もタリーカの指導を行っていた。

ハルワティーヤの具体的な活動はこの 1 人のシャイフとその直接の弟子たち からなるマジュリスが基本的な単位となっている。弟子としてのサーウィーの 姿勢からも分かるように，そこでは専らマジュリスの長である多ルディールヘ の絶対的な忠誠が求められ, 同じタリーカに属していても他のシャイフに師事 することは好まれていなかった。従ってこうしたマジュリスを実質上の「教団」 とみなすことができるかもしれない。そして修行を完成させイジャーザを得た 段階で, サーリフ・アッスィバーイーやアブドゥルアリーム・アルサンフーリー のように弟子は師のマジュリスから独立して自らがシャイフとなる新たなマ ジュリスを開く権利を得る。つまり新たな「教団」が生まれることになるので ある。

このように考えるとハルワティーヤ教団というのは無数に分裂してゆく支教 
団から形成される集合体として捉えることができるだろう。実際にこれまでの 研究においてはハルワティーヤ教団はそのような特徵を持つ教団として理解さ れてきた。例えばJ.S.トリミンガムはハルワティーヤ系の支教団としてバク リーヤ教団 Bakriyya，ハフナーウィーヤ教団 Hafnawiyya，サンマーニーヤ教 団 Sammaniyya, シャルカーウィーヤ教団 Sharqawiyya, ダルディーリーヤ教 団 Dardiriyya, ラフマーニーヤ教団 Rahmaniyya, サーウィーヤ教団 Sawiyya, タイビーヤ教団 Taybiyya の名前を挙げている。

しかし伝記の記述を詳細に検討すると，伝記作者たちはハルワティーヤをこ のような図式では捉えていなかったことが分かる。伝記の中でサーウィーを始 めとするスーフィーたちが属していたタリーカとして, 例えば iyya という形 で名前が挙がるのは八ルワティーヤだけであり，上述のようなそれ以外の名称 のタリーカは全く見出せない。伝記においてはサーウィーであろうと，年ル ディールであろうとクルディーであろうと彼らの所属した夕リーカはハルワ ティーヤという一つのタリーカとしか考えられていないのである。

その一方で具体的にサーウィーが修行を行ったり，シャイフとして活動を 行った単位は上述のように場としてはマジュリスと呼ばれたり，あるいはもっ と単純に「集団」(jamā'a, rifqa など) と呼ばれる。そしてシャイフとなった後 の伝記の記述を見ると，ハルワティーヤというよりもむしろサーウィーという 個人に結びついた集団として jamā'at al-Șāwī, jamā'at al-ustādh といった表 (43) 現がしばしばなされる。それは例えば次のような記述に見出される。

彼（サーウィ一）の弟子の一人がブハイラに商業に出かけた。彼がそこに 到着するとその地方のアミールが彼を不当に逮捕した。そこで彼（その弟 子）は言った。「私が逮捕されるのは正しいことなのだろうか。私は サーウィーの集団（jamā'at al-Șāwi）に属している(のに)。」

そもそもタリーカとは文字通りには「道」であり，つまりそれはある特定の 教義・儀礼・系譜である。伝記においては夕リ一カはまさにこの文字通りの意 味で理解されており，そこには具体的な社会的実体が必ずしも想定されている わけではない。従ってハルワティーヤの実体は，これまでの研究のように元の タリーカが下位のタリーカに分裂するという連続的な認識ではなく，タリーカ と実際の社会集団とのレベルの違いによって理解されるだろう。すなわち tarīqat al-Khalwatiyya はあくまでも一つであるが，それを実践する集団が無 
(45)

数にあるのである。従ってトリミンガムが挙げた上記の支教団も，ハルワティー ヤという母教団に対してそれが分裂した支教団ではなく，あくまでもハルワ ティーヤを実践するマジュリスのことを指していると考えた方がより正確な゙ろ う。

ただしマジュリスを単位とするこうした諸集団も一般的に理解されているよ うな「教団」と呼べるほどの組織ではなかったと考えられる。例えばそれはシャ イフ位の継承の問題に現れる。前述のとおり, サーウィーはダルディールのマ ジュリスに加わりそこで修行を行った。修行を終えると彼は師によってイ ジャーザを与えられる。このイジャーザは学問におけるものと同様で，その夕 リーカを人に教えることを許可するものである。つまりイジャーザを得た段階 で理念的には彼は弟子を取って師となること，すなわち独自のマジュリスを開 くことが許されるのである。そしてサーウィー自身はイジャーザを得な後もダ ルディールのマジュリスに長い間留まったが, ダルディールの生存中に独自の マジュリスを開いた同胞たちもいた。ダルディールが死亡するとそのマジュリ スは長を失って解体する。そしてまだ独自のマジュリスを持っていなかった サーウィーが同胞たちに自らのマジュリスに参加するように求められたのはす でに見たとおりだがここで重要なのはダルディールのマジュリスが サーウィーを含む弟子の誰かによって継承されずに消滅したということである。

一般的にスーフィー教団のシャイフの地位は世襲される場合が多い。それに よってその創始者の権威・カリスマが次の長にも継承され，その教団が保たれ てゆくのである。しかしハルワティーヤのメンバーの間ではこのような世襲に よるカリスマの継承が行われなかった。ムスタファ・アルバクリーにせよ，ム ハンマド・アルヒフニーにせよ，ダルディール，クルディーにせよ，史料にお いてはその血縁者についてはほとんど何も触れられていない。

世襲によらないシャイフ位の移譲はハルワティーヤの特徴の一つとしてこれ までの研究でも指摘されてきた。その代わりにシャイフが死前に後継者を指 定したり，あるいは弟子の間の選挙で選ばれると述べられてきた。しかし，年 代記や伝記のどこを見ても明確にそうしたシャイフ位の移譲を示したような記 (49) 述は見当たらない。確かに，その活動の様子から一番弟子と思われるような人 物の見当をつけることはできる。ダルディールの弟子たちの中では，後にその ザーウィヤを引き継いだという点でサーリフ・アッスイバーイーが主要な弟子 
であったとみなすことはできるだろう。しかしすでに見たとおり彼はダル ディールの生存中から自らのマジュリスを持っており，他の弟子たちに対して 特に優位であったという証拠も見出せない。

基本的にはマジュリスは師と弟子との一対一の個人的な関係によって維持さ れており，その師が死ぬと弟子は他の師を捜し求めるか自分が師の後継者であ ると自認してマジュリスを開いていったと考えられる。このようなマジュリス の姿は一般的な教団組織像からはかけ離れているだろう。

また例えばP.グランの述べるようなタリーカによる紐帯というものもこの 時期のハルワティーヤのメンバーの間では見られない。ダルディールと サーウィーのように師弟の関係は非常に密接であるが，サーウィーとサーリ フ・アッスィバーイーといった同胞とのつながりやサーウィーとマフムード・ アルクルディーといった他のシャイフとの紐帯を示すような記述はほとんど見 られない。確かに伝記においてはそうしたメンバー間の散発的な接触や，同じ タリーカの同胞 (ikhwān) という意識の発現は見られるが，タリーカに基づい た具体的なネットワークや結束といったものを示す証拠は見られない。アズ八 ルにおける人間関係はすでに述べたように法学派，地縁，エスニシティが第一 の要因として作用し，その上で夕リ一カの人間関係も作られるが，夕リ一カの つながりがそうした第一の要因に優先するということはなかった。

例えばダルディールの弟子にはマーリク派で上エジプト出身者が多いが（表 参照)，これは彼のアズハルにおける地位に基づくものだろう。あるいは1778年 にシャイフ・アルアズハルの地位をめぐってシリア人でハナフィー派のアブ ドゥルラフマーン・アルアリーシー 'Abd al-Raḥmān al-'Arīshī (d.1779) とエ ジプト人でシャーフィー派のアフマド・アルアルースィーAhmad al'Arūsī (1720/21-1793）が熾烈な争いを展開した事件も例としてあげることが できるだろう。この事件は当時のカイロの名士たちを巻き込んだ大規模なもの となった。そこではマムルーク間の対立，バクリー家とサーダート家との対立， アズハルにおける法学派・エスニシティの対立が浮き彫りにされている。両者 は共にハルワティーヤのメンバーであり，またダルディールやムハンマド・ アッサマンヌーディー Muhammad al-Shāfi'‘̄ al-Samannūdī (1687/88-1784/ 85）といった他のメンバーもこの争いに加わったが, 彼らはそれぞれ法学派や エスニシティに基づいて参加し, そこにはハルワティーヤへの帰属に基づく連 
帯は全く見出されない。

またスーフィー間のつながりがあったとしても，それは必ずしもハルワ ティーヤというタリーカの枠内に限定されるものではなかったと考えられる。 これは例えばサーウィーが独自のマジュリスを開く際の象徴的な出来事が参考 になるだろう。そこで彼は 4 つの夢を通して許可を与えられたが，それらの夢 にはムハンマドをはじめとする預言者たち，アフマド・バダウィーをはじめと する過去の聖者たちが現れた。このような預言者たちや有名な聖者たちが夢に 現れるというのは，サーウィーが単なる一タリーカのシャイフというだけでは なく，普遍的な聖者であったということを示す意困があるだろう。またそれ以 外にもダルディールや同胞のサーリフ・アッスイバーイーといったハルワ ティーヤのメンバーも現れている。そして興味深いことにこの夢には彼の シャージリーヤにおける師であるガライニーや，同じくシャージリーヤとブル ハーミーヤ al-Burhāmiyya のスーフィーであったイーサー・ガーズィー 'Isāa Ghāzì という人物も現れてサーウィーに許可を与えている。

サーウィーが開くマジュリスはハルワティーヤの教えを実践するマジュリス であり，一見すれば他のタリーカのスーフィーの許可を得る必要はないと思わ れる。しかしこのように他のタリーカのメンバーの許可が必要とされたという ことは，彼がハルワティーヤという枠を超えたスーフィーたちとの関係の中で 生きており，彼らの権威やサーウィーに対する評価というものも重視されてい たことを示唆するのではないだろうか。

以上の考察により，この時期のハルワティーヤの構造は次のように理解され るだろう。まずハルワティーヤ教団といった時，それを特定の教義や儀礼をも つ社会組織として考えるのは誤っている。実際には特定の教義・儀礼・系譜一 つまり信仰の様式一を示すタリーカのレベルと, それを実践する集団のレベル とに分けて捉える必要がある。そしてこれらの集団はそれぞれのシャイフとの 個人的な結びっきによって成り立っており，組織性や持続性が欠如している。 さらにメンバー間の横の結びつきは非常に弱く，彼らの活動は夕リーカの枠組 みでは捉えきれない。

むしろある個人はハルワティーヤを学んだから自動的にハルワティーヤの スーフィーとなるのではなく，本人なりその弟子たちなりが後から彼をハルワ ティーヤのスーフィーであると規定してゆく側面もあったのではないだろうか。 
タリーカとしてのハルワティーヤは正統的な教義を持つと評価されており，ま たヒフニーのような著名なウラマーがハルワティーヤのシャイフとして知られ ていたことを考えれば，この時期のハルワティーヤにはそれだけの権威もあっ たと考えられる。

いずれにせよハルワティーヤが何らかのまとまりを持っていたとすれば，そ れはメンバーが同じ教義を持ち儀礼を行うというタリーカのレベルであり, 現 実の社会にはハルワティーヤという言葉で表現できるような組織やネットワー クなどを——少なくともアズハルの学識者の間では一一見出すことはできない のである。

\section{19世紀における教団組織の変化}

本稿で示してきたハルワティーヤの像は伝記や年代記の作者たちすなわちア ズハルの学識者の社会における教団のあり方であってその点で限定的なもので ある。しかし同時代のメンバー自身のこのような認識を指摘することで，これ までの研究で前提とされていた教団組織像の問題点を具体的に明らかにし, そ れに修正を迫ることができたのではないだろうか。

教団組織の㛜密性についてはこれまでにも問題にされることはあったが，こ こで明らかにされたハルワティーヤ教団の害態はその厳密性の問題以前に明確 に定義できる「教団組織」そのものの存在を疑う結果となった。

他方これまでの研究に扔いてこうした「教団組織」が前提とされてきた要因 の一つには，現代のエジプトにおける教団組織の姿がそのまま反映されている という点を挙げることができるだろう。19世紀を通して主に政府による行政改 革の結果，ハルワティーヤ教団は現代のような「教団組織」を持つ社会集団へ と変化したのである。ではその変化とは一体どのようなものだったのだろうか。 この点についての詳細な研究は今後の課題であるが, 最後にそうした变化の大 まかな見取り図を示して本稿を終えることにしょう。

1880年代に書かれたアリー・ムバーラクの地誌やそれ以降の史料には八ルワ ティーヤ系のタリーカ（al-țuruq al-șūfiyya）の名前が挙がっているが，こうし たタリーカは同時に世襲される長を持つ明確な一つの集団としても成り立って いたようである。すなわち19世紀を通してハルワティーヤは下位のタリーカへ と分裂し，またそうしたタリーカが同時に社会集団の名前でもあるような教団 
へとその構造が根本的に変化したのである。そしてこのような変化の最も大き

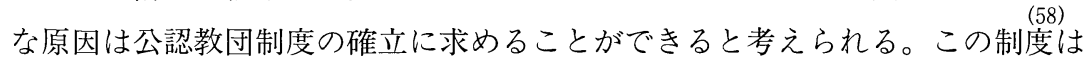
バクリー家のシャイフが各教団のシャイフの権威を保証したり教団の活動を保 護・管理するものであったが，それは同時に各教団（夕リ一カ）に一人の長を 求めるものであった。むしろこの制度の成立そのものが, 多くの教団でそこで のシャイフの地位をめぐって後継者争いが起こった際に, バクリ一家のシャイ フに仲裁を求めたことに起因している。従って，この制度の下では各夕リーカ が同時に一人の長を戴く集団としても確立することになる。そしてそれが維持 できない場合には支教団（タリーカ）という形で分裂することが求められるの である。

ただし公認教団制度は基本的にはそれにメリットを感じるシャイフが自主的 に参加する強制力のない制度であり，ハルワティーヤのシャイフたちは長い間 この制度下には入らなかった。しかしハルワティーヤそのものの側にも19世紀 以降ある程度の組織化が現れており，それもあってか最終的には一確認でき る限り1872年には一一公認教団となる。これによって本稿で示したような一つ のタリーカと複数の集団というあり方は成立しなくなり，各集団ごとにタリー カとして独立することが求められたと考えることができる。19世紀においては ハルワティーヤ系の支教団が無数に成立したことはよく知られているが，その

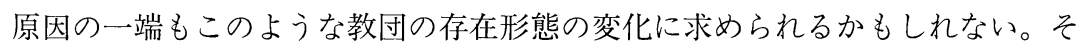
して公認教団制度がエジプト全土の教団を対象にしていたことを考えれば，少 なくともその傘下に入った他の多くの教団においても同様の存在形態そのもの の変化が生じたと考えるべきだろう。逆に言えば, 公認教団制度が確立する以 前のエジプトの教団を考える際には，こうした変化を十分に踏まえて臨む必要 がある。そしてその際の認識の枠組みの一つとして, 本稿で示したハルワティー ヤのあり方が参考になるのではないだろうか。

注

(1) 例えば E. Bannerth, "La Khalwatiyya en Egypte," Mélanges de l'Institut Dominicain d'Etudes Orientales du Caire 8 (1964), 1-74; id., "La Rifa'iyya en Egypte," Mélanges de l'Institut Dominicain d'Etudes Orientales du Caire 10 (1970), 1-35; N. Clayer, "La Khalwatiyya (Khalvetiye)," in A. Popovic \& G. Veinstein(eds.), Les Voies d'Allah: Les Ordres Mystiques dans l'Islam des Origines à Aujourd'hui, Paris, 
1996, 484-491; E. Geoffroy, "La Chadhiliyya," in A. Popovic \& G. Veinstein (eds.), Les Voies d'Allah., 509-518; F. de Jong, "Mustafa Kamal al-Din al-Bakri (16881749): Revival and Reform of the Khalwatiyya Tradition?” in N. Levtion \& J. O. Voll (eds.), Eighteenth-Century Renewal and Reform in Islam, Syracuse, 1987, 117132; B. G. Martin, "A Short History of the Khalwati Order of Dervishes," in N. R. Keddie(ed.), Scholars, Saints, and Sufis: Muslim Religious Institutions in the Middle East since 1500, Berkeley, 1972, 275-305. など。

（2）例えば古林清一「18・9 世紀エジプト社会と民衆宗教」『イスラム世界』12(1977), 15-36; 同「神秘主義教団の実像」佐藤次高（編）『イスラム——社会のシステム』(講 座イスラム 3 ) 筑摩書房, 1986, 149-182; G. Baer, Egyptian Guilds in Modern Times, Jerusalem, 1964; P. Gran, Islamic Roots of Capitalism: Egypt, 1760-1840, Austin, 1979; J. Heyworth-Dunne, An Introduction to the History of Education in Modern Egypt, London, 1938: A. Raymond, Artisans et Commerçents au Caire au XVIII ${ }^{e}$ siècle, 2 Vols., Damascus, 1973-74; S. J. Staffa, Conquest and Fusion: The Social Evolution of Cairo A. D. 642-1850, Leiden, 1977. など。

(3) E. W. Lane, An Account of Manners and Customs of the Modern Egypt: Written during the Years 1833-1835, London, 1836 (1895ed. rep. 1981.) の迷信を扱った項な ど (244-509)。

(4) M. Winter, Egyptian Society under Ottoman Rule, 1517-1798, London \& New York, 1992, Chap. 5 “The Sufis,” 128-166.

( 5 ) Winter, op. cit., 133.

( 6 ）Winter, op. cit., 132. またしばしばこれにパラレルな関係をなすものとして「正統 的教団」「異端的教団」という分類も用いられる。

（7）エジプトのハルワティーヤ教団に関する研究としては Bannerth, op. cit.; Clayer, op. cit.; The Encyclopaedia of Islam, new ed., s. v. KHALWATIYYA; Martin, op. cit. 参照せよ。

( 8 ) Ismā'îl 'Abdullāh al-Maghribī, Qāsim al-Shishtī, Aḥmad al-Shishtī, Muhammad al-Kutubī, Muhammad al-Ṣāwī, Al-Nūr wa'l-Wuḍ̂ā' fì Manāqib wa Karāmāt 'Umdat al-Awliya ', Cairo, 1928.（以後本文中では伝記，引用する際はNūr と略記）。 ムハンマド・アルクトゥビーの死後もアフマド・アッサーウィーの弟子たちに関する 記録の蒐集が後継者によって続けられ，最終的にはサーウィーの伝記にその弟子たち に関する記述が加えられてイスマーイール・アブドゥッラー・アルマグリビーによっ て出版された。

( 9 ) 'Abd al-Raḥmān al-Jabartī, 'Ajā'ib al-Āthār fi 'l-Tarãjim wa'l-Akhbār, 4 Vols., Būlāq, 1879-90（以後本文中では年代記，引用する際は 'Aja' $i b$ と略記）

(10) 'Ajā'ib, Vol. 1, 165; Yūsuf Ismā'īl al-Nabhānī, Jāmi' Karāmāt al-Awliyā', Cairo, 1962 （20世紀前半に書かれた聖者伝。以後 $J a \bar{a} m i$ と略記），Vol. 2, 471-472. ただしす 
でに1500年ごろからカイロではダムルダーシーヤ教団 al-Damurdāshiyya とグルシャ ニーヤ教団 al-Gulshaniyya というハルワティーヤ系の 2 つの教団が活動をしていた。 ただし両者の活動はカイロの主にトルコ系の住民に限られており，カラバシーヤ教団 とは別の系統でもあるので本稿では扱わない。cf. De Jong, op. cit., 122.

(11） 'Ajä'ib, Vol. 1, 289-304; Jāmi', Vol. 1, 347-361. 年代記の死亡録にはその弟子とし て25人の名前が挙がっている。

(12) 'Ajā'ib, Vol. 2, 61-68; Jāmi', Vol. 1, 362.

(13) 'Ajä'ib, Vol. 4, 159-165.

(14) 'Ajā'ib, Vol. 2, 147-148; Jāmi', Vol. 1, 564; Muhammad al-Bashīr Zääir, AlYawāqūt al-Thamīna fì A'yān Madhhab 'Ālim al-Madīna, Alexandria, 1906-07 (マー リク派法学者の人名辞典。以後 Yawāqit と略記), 56-57.

(15) Yawāqìt, 171-172.

(16) 'Alī Mubārak, Al-Khițt al-Tawfĩqiyya al-Jadīda li-Miṣr al-Qāhira wa Mudunihā al-Qadìma wa 'l-Shahīra, Būlāq, 1886-89 (以後 Khitat と略記), Vol. 6, 35-36.

(17）聖者としてのサーウィーに関する研究は G. Delanoue, Moralistes et Politiques Musulmans dans l'Egypte du 19e siècle (1798-1882), Cairo, 1982, Vol. 1, 185-242 にお いてなされているが，そこではサーウィーが活動を行った教団に関する考察はなされ ていない。

（18）サーウィーについての情報源としては伝記以外にも Yawāqüt, 64-65. Jāmí, Vol. 1, 575-576. を参照せよ。

(19) Khitat, Vol. 13, 2-4.

(20) 彼の血筋については $N \bar{u} r, 21-22$.

（21）出生からアズハルに行くまでの記述は Nūr，24-27.このように故郷の村でコーラ ンを暗誦をしてからアズハルへ行くというのは当時の典型的なウラマーの学歴パター ンである。cf. Heyworth-Dunne, op. cit., 2-7, 36.

(22) Nūr, 27-30.

(23) 'Ajā'ib, Vol. 4, 284-286.

（24） Nūr , 30. また後述するようにムハンマド・アルアミールからも後にタリーカを学 んでいる。

(25) Tuhfat al-Ikhwān fī Ā dāb al-Ṭariq. 本稿では Bannerth, op. cit. に収められてい る仏訳を使用した。

(26) Bannerth, op. cit., 29-43.

(27) Nī $r, 43$.

（28）伝記には，アズハルの学生の中にはズィクルやウィルドを学ぶも「多くの人々に 会うことを考慮して」タリーカに入信するのを避けていた者たちがいたと述べられて いる。 $N \bar{u} r, 35$.

(29) 'Ajā'ib, Vol. 1, 296; Bannerth, op. cit., 49-51; Nūr, 35. 
(30) Khitat., Vol. 6, 27.

（31）例えば弟子が守るべき規範の一つには次のようなものがある。「シャイフの許可な

しに生きている聖者や敬虔な人への参詣を行わない。他の人の祈りの集いにも参加し てはいけないし，自分のシャイフの秘密の水を全て飲み終える前に他の人の話を聞い てもいけない。」(Bannerth, op. cit., 24.)

(32) $N \bar{u} r, 34$.

(33) Nūr $, 36,42$.

(34) Nū $r, 37-38$.

（35）彼は八ナフィー派のアーリムでもあった。'Ajā'ib, Vol. 2, 60.

(36) Nūr, 38; 'Ajā'ib, Vol. 4, 284.

(37) $N \bar{u} r, 39$.

(38) Nūr, 38-39.

(39) $N \bar{u} r, 39-42$.

(40) さしあたっては J. S. Trimingham, The Sufi Orders in Islam, Oxford, 1971, 173193 の教団組織の説明を参照。

（41）Ibid., 75-76. 細かいくい違いは見られるが，他の研究でも同様の支教団名を挙げ ている。恐らく最初にそうした区分をしたのは A. Le Chatelier, Les Confréries Musulmanes du Hedjaz, Paris, 1887, 51-57. だろう。

（42）ほとんどの場合単に tarīqa（あるいは țarīq）としか書かれていない。(Nūr, 30, 31, 39, 42, 49, 54 など)。ちなみに年代記においても同様であり，ハルワティーヤかあ るいは場合によってはカラバシーヤという名称しか見出されない。(例えば 'Ajāib, Vol. 1, 294)。むしろこのような支教団名は史料に基づくというよりも，思想的意義や あるいは系譜上の理解に基づいて研究者が恣意的に作り出したり, あるいは最後の章 で触れるように19世紀の後半以降の組織化の進んだ教団の像が反映されている側面も あるだろう。例えばバクリーヤ教団については De Jong, op. cit. の中でその存在が否 定されている。

（43）例えば $N \bar{u} r, 50,58,60,69,78$ など。

(44) Nūr, 55. ちなみにこの後彼はサーウィ一の奇蹟によって助け出される。

（45）ちなみにこのようなタリーカのレベルと実際の社会集団とのレベルの違いによる 教団への認識はハルワティーヤだけでなく他の教団にも当てはめることができるので はないかと推測できる。例えばアフマディーヤ教団 al-Ahmadiyya は研究では通常「民 衆的」「異端的」性格を持つとして認識されているが，年代記においてはアフマディー ヤ教団に入信しているウラマーも数多く見出されまた彼らに対して非難がされること はない（'Ajā'ib, Vol. 1, 84, 337, 376, Vol. 2, 260 など)。それに対してマウリドなどで 実際にアフマディーヤ教団の名前が挙がる際にはジャバルティーは民衆の存在を述べ, またそこに非難と軽䓹を示している。彼の記述をよく検討するとウラマーが入信した 教団として語られる際には tarīqat al-Ahmadiyya という表現がなされるのに対して, 
実際に活動する集団に対しては例えば「アフマディーヤやリファーイーヤやカーディ リーヤやブルハーミーヤなどの有名な聖者廟（al-darā’ih）の類に自らを結び付けてい る卑しい職業に属する者たち (arbāb al-hịraf al-mardhūl)」( 'Ajā'i b, Vol. 4, 120)や「ア フマディーヤやサアディーヤやシュアイビーヤといった (タリーカの儀礼の) 方法 (alțarā'iq) に従う下層民（awbāsh al-‘̄alam)」('Ajā'ib, Vol. 4, 190) といった表現がなさ れており，彼がタリーカではなくその名前を語る特定の集団を想定していることが分 かる。これはジャバルティーが，ウラマーが学ぶ夕リーカと実際に人々がその名前の 下に構成する集団とを別のレベルで捉えていたことを示唆するだろう。またM.ウィン ターが述べるシャーラーニー 'Abd al-Wahhāb al-Sha'rānī (d. 1565/66) のスーフィズ ム観も参考になるだろう。シャーラーニーはアフマディーヤに属していたが，同時に 彼は他のアフマディーヤのメンバーを非難していた。ウィンターはこの矛盾を, シャー ラーニーがスーフィズムをある教団に属したり聖者崇帱をおこなうことではなく， シャイフに道を学ぶことであると考えており,彼が非難したのはアフマド・バダウィー という聖者を崇拝する人々であったと解釈している。M. Winter, Society and Religion in Early Ottoman Egypt: Studies in the Writings of 'Abd al-Wahhäb al-Sha'rānī, New Brunswick \& London, 1982, pp. 99-101. 実際のところ，ジャバルティーやシャーラー ニーが非難したこれらの集団というのはアフマド・バダウィーを聖者として崇拝する だけの集団であって, タリーカとしてのアフマディーヤとは思想的なつながりさえも 見出せないような集団であった可能性もある。従ってこれらの集団を「夕リーカとし てのアフマディーヤに対してそれを実践する集団」とするのは誤っているかもしれな い。ただし，そうした聖者崇扯とスーフィズムとの区別の問題は（非常に重要である が）本稿で扱うテーマを越えているため，別の機会に論じてゆきたい。ここではとり あえずこれまでの研究が, タリーカとしてのアフマディーヤとそれを名乗って活動す る諸々の集団を共に同じ「アフマディーヤ教団」とひとくくりにして諭じてきたこと の問題性を指摘するに留めておく。

(46) 'Ajāib, Vol. 1,296にヒフニーに与えられたイジャーザの全文が, Bannerth, op.cit., 45 にダルディールに与えられたイジャーザの全文が引用されている。

(47) ヒフニーについてはその孫ムハンマド・ユースフ Muhammad Yūsuf al-Hifnī に ついて年代記で 1 箇所言及されているが，タリーカの中での位置づけは不明であり， 他の部分では全く言及されてない。'Ajā'ib, Vol. 4, 76.

(48) Martin, op. cit., 302; Trimingham, The Sufi Orders, 173-174; Winter, op. cit., 151.

(49）例えばB.G.マーティンが，マフムード・クルディーがヒフニーの後を継いだ根拠 としている年代記の記述では単に「彼（クルディー）のシャイフの死後彼は教育と指 導（al-irshād, al-taslik）を行った」としか書かれていない。'Ajā'ib, Vol. 1, 298.

(50) Khitat, Vol. 6, 27.

（51）修行を完成していないムリードが師の死や他の理由によって，同じ夕リーカの他 の師を探すという例も時々見られる。cf. Nūr r, 49; 'Ajāảib, Vol. 4, 160; Yawāqüt, 171. 
(52) Gran, Islamic Roots of Capitalism, 35-37.

(53) $N \bar{u} r, 31,58,74-75$.

(54) 'Ajaj'ib, vol. 2, 83-85. 多ディールはマグリブの学生たちと共にアリースィーの 側につき，一方サマンヌーディーはシャーフィイー派としてアルーシーについた。

(55) $N \bar{u} r, 41-42,90$.

（56）例えば20世紀以降の教団に関する研究であるが, M. Gilsenan, Saint and Sufis in Modern Egypt: An Essay in the Sociology of Religion, Oxford, 1973, 65-66 で教団組織 の性格を巡る議論がなされている。

(57）Khitat, Vol.3, 129-130. の「現在バクリー家のシャイフの下にあるスーフィー教 団一覧」ではハルワティーヤ系の教団としてヒフニーヤ al-Hifniyya, シバーイーヤ alSibā‘iyya，サーウィーヤ al-Ṣāwiyya，ダイフィーヤ al-Ḍayfiyya の名前が挙がってい る。あるいはそれ以外の代表的な史料としてはバクリー家のシャイフによって書かれ た Muhammad Tawfīq al-Bakrī, Bayt al-Siddīq, Cairo, 1905-06, 381-394. の「イス ラーム世界のスーフィー教団」という章があるがここではなぜかダイフィーヤの名前 しか見出せない。

(58) 詳細については F. de Jong, Turuq and Turuq-linked Institutions in 19th Century Egypt: A Historical Study in Organizatioal Dimensions of Islamic Mysticism, Leiden, 1978. 